\title{
Chicago Haymarket Centennial
}

\author{
Jerry Lembcke \\ Lawrence University \\ Carolyn Howe
}

University of Wisconsin

Give me your tired, your poor, your huddled masses,

The wretched refuse of your teeming shore.

Send these, the homeless, tempest-tossed to me,

I lift my lamp beside the golden door.

Inscription on the Statue of Liberty

Dedicated October 28, 1886

I found long ago, that the workingman had no more rights here than anywhere else in the world. . . . and just as the man who agitated against slavery in this country had to ascend the gallows, so must we. He who speaks for the workingman today must hang.

George Engel, Haymarket Martyr October 8, 1886

As six hundred dignitaries watched the unveiling of the Statue of Liberty one hundred years ago, eight Chicago working-class leaders sat in the Cook County Jail. They had been convicted of conspiring to throw a bomb that killed a policeman at a May 4, 1886 labor rally in Haymarket Square. Four of them, Albert Parsons, August Spies, George Engel, and Adolph Fisher, would be hung on November 11, 1887. Except for Parsons, they were all immigrants.

Just as the juxtaposition of the epigrams underscores the inconsistency between the image of justice and freedom promised by the Statue of Liberty and the reality as nineteenth-century workers experienced America, the conviction one hundred years later of church workers for providing sanctuary to refugees fleeing Central America stands in stark contrast to the glitz and glitter surrounding the statue's rededication. The statue's promise has proven chimerical while the words of George Engel have proven prophetic.

In 1886 the Haymarket affair was vastly more important than the dedication of the Statue of Liberty. Yet today advertisers and conservative ideologues have been able to rivet national attention to the patriotic symbolism surrounding the statue while Haymarket is all but forgotten. This underscores just how seri-

International Labor and Working-Class History

No. 31 , Spring 1987 , pp. $96-98$

(C) 1987 by the Board of Trustees of the University of Illinois 
ously our history has been distorted and heightens the significance of the efforts made by a few organizations and individuals to commemorate the Haymarket centennial.

Several events were held in Chicago between May 1 and May 4 to mark the occasion. The kick-off event for the weekend was the primero de mayo march through the Pilsen neighborhood. Pilsen was the core working-class district out of which emanated many of the organizing activities leading to the Haymarket affair. Today, Pilsen is primarily a Spanish-speaking neighborhood and the annual May Day parade through its streets reflects the issues and concerns of these latest immigrants. This year's march was joined by members of the IWW, who were in the city for a conference on anarchism held at RuizBelvis Cultural Center. An IWW-sponsored program on labor in Poland and Eastern Europe followed the Pilsen march.

One of the largest events of the weekend was the Friday, May 2 International Mayday Festival held at Juarez High School. The evening activities were sponsored by the Haymarket Centennial International Committee, a coalition of groups that included AFSC, CISPES, Venceremos Brigade, the Midwest Center for Labor Research, and several left-wing organizations. The program, lasting over four hours, included speakers and entertainment from the FDRFMLN and the African National Congress. Of all the events of the weekend, this program symbolized more than any others the lessons of Haymarket: the need for international solidarity among working people and an end to class rule and oppression, whatever its form. In the spirit of May Day, the program was open to people of all ages, nationalities, and affiliations.

Between the scheduled events, individuals and groups from outside Chicago visited the numerous historical exhibits commemorating Haymarket. Among the more popular exhibits were those at the Chicago Historical Society, Hull House, and the Chicago Peace Museum.

The centerpiece of the weekend was Haymarket Revisited, a Saturday, May 3, conference at the University of Illinois, Chicago Circle campus sponsored by the Illinois Labor History Society and the Chicago Federation of Labor. A dramatic presentation in three parts by members of Actors' Equity Association, AFL-CIO, portrayed the events leading up to and culminating in the Haymarket bombing, the trial, and the execution of the martyrs. The acting and staging of the dramatization were outstanding, and the script was politically energizing and powerful. The reenactment of the trial was particularly well done, in that eight or ten actors were able to vividly and accurately portray the long, complex, and farcical trial in a mere thirty minutes. Between the three acts of the dramatization were panel discussions on the history, legal issues, and legacy of Haymarket. The afternoon program included addresses by labor leaders on Chicago as a union town and the current situation of workers and their unions and an address by Senator Paul Simon. These talks were highlighted by dramatic presentations entitled "Not Working" and "The Union Makes Us Strong." The program ended with the singing of "Solidarity Forever." 
The goals of the conference were to provide an understanding of the Haymarket affair and its relationship to the eight-hour movement and the labor movement of that period as well as an understanding of the lessons of Haymarket for the current labor movement. Unfortunately, many of those lessons seem to be lost on today's union leaders. Symptomatic of the defensive and overly cautious posture characteristic of many union leaders, attendance at the conference was limited to those who had one of the thousand tickets handed out selectively before the conference. It was rumored that the planners feared disruptive activities of anarchists, left groups, or others not specifically approved by the AFL-CIO. The sad result was that more than one-half of the seats remained empty at the conference while people who came from a distance to be a part of the Haymarket Centennial were reportedly denied entrance. One can imagine what the Haymarket martyrs themselves would have said, had they been stopped at the door for not having a ticket to the conference. Nevertheless, despite what appeared to some as an exclusionary attendance policy, it is commendable that the Chicago Federation of Labor took this occasion to bring to some of its members this important aspect of their own history.

Running parallel to the conference at Circle Campus were a conference at the Newberry Library on German-American workers and the semi-annual meeting of Labor Education Local 189. An evening of labor song and conviviality at the Moosehead bar sponsored by Local 189 provided a unifying end to a busy and stimulating day.

May 4 began with a morning ceremony at Waldheim cemetery where the Haymarket martyrs are buried. The burial site is marked by a monument bearing the words spoken by August Spies as he stood, hooded, with a noose around his neck moments before hanging: "The time will come when our silence will be more powerful than the voices you strangle today." Around the monument are buried several family members of the martyrs, including Lucy Parsons, and many individuals notable for their contributions to labor and U.S. radicalism. Among the interred at Waldheim are William Z. Foster, Emma Goldman and Elizebeth Gurley Flynn. Songs were offered by Utah Phillips and other singers, including Allen Schwartz, who wrote and sang a tribute to Governor John Peter Altgeld, the governor who eventually pardoned the Haymarket defendants. The major theme emphasized at the ceremony was the importance of the struggle for freedom of free speech and for the eight-hour day.

Following the memorial program at Waldheim several hundred people joined striking Chicago Tribune workers at a downtown rally. Speeches, music, and discussion filled the early afternoon before the participants marched, with a horse-mounted police "escort," to the site of the Haymarket bombing and police attack.

At the Haymarket site another rally was held, with speakers, dancers, and musicians all emphasizing that the lessons of Haymarket are found in the international struggle of working people for freedom from economic exploitation and racial, gender, and political oppression. 